This is the author's Post-print version (final draft post-refereeing as accepted for publication by the journal). The definitive, peer-reviewed and edited version of this article is published as: Feijten P.M. and van Ham M. (2010) The impact of splitting up and divorce on housing careers in the UK. Housing Studies 25, 483507. http://dx.doi.org/10.1080/02673031003711477

\title{
The impact of splitting up and divorce on housing careers in the UK
}

PETEKE FEIJTEN \& MAARTEN VAN HAM

University of St Andrews, Longitudinal Studies Centre - Scotland, School of Geography and Geosciences, Irvine Building, North Street, St Andrews KY16 9AL, UK. Email: peteke.feijten@st-andrews.ac.uk

\begin{abstract}
Using 1991-2004 data from the British Household Panel Survey (BHPS) this paper analyses the effect of union dissolution on the occurrence of moves, changes of dwelling type, and the probability of moving out of owner-occupation. The main contributions of this paper are that we take into account the rise in the occurrence of cohabitation, by analysing the dissolution of cohabiting and marital unions separately, and that we study the effect of repartnering on housing careers. Using logistic regression models we found clear evidence that the dissolutions of marriage and cohabitation result in different housing career outcomes. In particular, those who divorce experience a larger drop in housing quality than do those who split up from cohabitation. Starting a new relationship leads to more upward moves in the housing career compared to remaining divorced or split up.
\end{abstract}

Keywords: home ownership, housing career, longitudinal data, residential mobility, union dissolution.

\section{INTRODUCTION}

Divorce rates in many Western European countries have increased strongly over the last decades. In the UK, the yearly number of divorces increased from around 25 thousand in 1960 to almost 150 thousand in the early 1980s (ONS, 2007a). Since then the number of divorces has remained fairly constant. With the rise in divorces a body of literature emerged in the 1980s and 1990s which studied the effects of separation (still legally married but living apart) and divorce on housing careers (Sullivan, 1986; Schouw \& Dieleman, 1987; Clapham et al., 1990; Jackson, 1990; Murphy, 1990; Symon, 1990; Wasoff \& Dobash, 1990; Watchman, 1990; McCarthy \& Simpson, 1991; Van Noortwijk et al., 1992). These studies show that divorce has a disruptive effect on the housing careers of those involved, often leading to downward moves on the housing ladder: moves from large to smaller and lower quality dwellings, moves from owner-occupation into rented housing and from single-family dwellings into multi-family dwellings (Feijten, 2005). Union dissolution is thought to have a disruptive effect on housing careers because associated moves are deviant compared to moves triggered by other life events: they are urgent and often financially restricted 
(Feijten \& Van Ham, 2007). These factors are likely to cause those who experience a union dissolution to move to different types of housing than other households.

Since the 1990s, academic interest in the effect of divorce on housing careers has diminished (exceptions are: Böheim \& Taylor, 2000; Flowerdew \& Al Hamad, 2004; Feijten \& Van Ham, 2007), mainly because divorce rates stabilised and because the impacts of divorce seemed well documented. There are however two reasons why renewed attention for the effect of union dissolution on housing careers is justified. The first is the rise in the occurrence of cohabitation. Since the early 1970s the number of marriages in the UK has dropped from 425,000 a year to roughly 275,000 a year (Figure 1) (ONS, 2007b). Although there are no official statistics available on the number of cohabiting unions, we know that the number of unmarried cohabiters has increased dramatically. This is illustrated in Figure 1, where live births to unmarried mothers are used as a proxy for cohabitation (ONS, 2007d).

\section{--- FIGURE 1 ---}

Unmarried cohabitation has now partly replaced marriage as a durable form of living together, although for many couples cohabitation is still mainly a precursor to marriage: around $60 \%$ of cohabitations continue onto marriage (Kiernan \& Estaugh, 1993; Ermisch \& Francesconi, 2000). Cohabitation differs from marriage because, as Rindfuss and Vandenheuvel (1990, p.707) put it, "cohabitation does not assume a commitment to permanency of the relationship. The necessity of a long-term commitment does not exist, although there may be an understanding that this is a distinct possibility". Only a small group of successful cohabiters will remain unmarried (around 10\%), and these cohabitations are more permanent and have the same durable character as a marriage (Kiernan \& Estaugh, 1993). The rise in cohabitation has led to an increase in the number of people who have ever experienced the break-up of a cohabiting union. Research has shown that around 30\% of cohabitations dissolve within 10 years (Ermisch \& Francesconi, 2000). In this study we will refer to the dissolution of non-marital status as 'splitting up'.

The dissolution of marital and non-marital unions may have different consequences for housing. As cohabitations often have a trial character, cohabiters may have invested less in their housing situation than married partners, and thus there is less to lose when cohabiters split up. Feijten and colleagues (2003) showed for the Netherlands that at young ages, married couples are much more likely to become homeowners than cohabiting couples. However, at somewhat higher ages cohabiting couples are just as likely to become home-owners as married couples, illustrating the long-term commitment of cohabitation for some couples (Feijten et al., 2003). For these durable non-marital unions, dissolution may have similarly severe effects on the housing career as for the dissolution of a marital union. As far as we know, the effect of the dissolution of non-marital unions on housing has not been studied so far.

The second reason for renewed attention for the effect of union dissolution on housing careers is that although divorce rates have stabilised, the number of people in the UK who have ever experienced a divorce increases with more than a hundred thousand every year. Figure 1 illustrates that a large proportion of these people will remarry: the time series show an increase in the percentage of marriages where the husband was previously divorced (ONS, 2007c). Although the number of divorced women who remarry is lower, their numbers too are considerable. The literature suggests that remarriage has a positive effect on people's psychological and material wellbeing (Amato, 2000; Poortman \& Fokkema, 2001), and has a positive effect on 
housing careers in terms of dwelling (Holmans, 2000) and neighbourhood quality, especially for women (Murphy, 1990; South \& Crowder, 1998). In this paper we will therefore also study the effect of repartnering on the housing career.

This paper will contribute to the existing literature on union dissolution and housing careers in three ways. First, we will update analyses of the occurrence of moves, changes of dwelling type and the probability of moving out of owneroccupation. Second, we will study both the effect of splitting up and divorce on various aspects of the housing career. And third, we will look at the effect of repartnering on the housing career. We will use 1991-2004 British Household Panel Survey (BHPS) data and logistic regression models.

\section{BACKGROUND}

\section{Post-divorce housing and mobility in the UK}

The effects of divorce on housing are well documented up to the late 1980s. Clapham and colleagues (1990) found that after separation and divorce, men were more successful in staying in owner-occupation than women (50 versus 44 per cent, see also Symon, 1990). Twice as many moving divorcees reported a decrease in the number of rooms available than divorcees who reported an increase (Wasoff \& Dobash, 1990). A lack of amenities was twice as common among divorced women than among married women (Murphy, 1990) and those divorced women were often childless and lived in the private rented sector. Divorced people, even when they have children, were also reported to be less likely to live in single family dwellings than married couples (Sullivan, 1986; Murphy, 1990).

In the UK, most married couples are homeowners (around $80 \%$ in 2001, see Wilcox, 2003), and although the divorce rate among homeowners is a quarter to a third lower than among renters (Holmans, 2000), their greater number means that most divorces involve decisions on who stays (if anyone at all) in the matrimonial owner-occupied home. McCarthy and Simpson (1991) found that of all divorcees who left an owner-occupied matrimonial home upon separation, only $36 \%$ stayed in owner-occupation, but three years after the divorce, the share of them living in owneroccupation had risen to $75 \%$. A similar pattern of recovery was found for council tenants: the largest group of separating council tenants moved into shared housing, but three years after a divorce, $62 \%$ per cent of them lived again in council housing. These figures indicate that downward moves on the housing ladder are often only temporary. Several studies show that it takes a series of moves before divorced people live again in housing they see as suitable (McCarthy \& Simpson, 1991; Watchman, 1990; Jackson 1990). McCarthy \& Simpson (1991) found that 20\% of their sample made more than two moves in the period after separation (up to three years after divorce). Divorcees with dependent children made fewer moves (a maximum of five) than those without dependent children (some of whom made more than eight moves).

Wasoff and Dobash (1990) found different effects of union dissolution on housing at the moment of separation, the period between separation and divorce, the moment of divorce, and the post-divorce period. The initial separation was found to lead to a move by one of the partners, and in some cases by both. In the period between separation and the divorce settlement, the majority of people moved house at least once, and often more than once. Symon (1990) found that at the moment of separation, women more often stay in the matrimonial home than men. This gender difference was larger when the couple had lived in the house longer, and when the 
couple had dependent children (Symon, 1990; Wasoff \& Dobash, 1990). However, at the moment of the divorce settlement or court order, there was a new wave of moves out of owner-occupation, either immediately upon the divorce, or after some time. Sullivan (1986) found that the probability of moving out of owner-occupation for divorced women increases some time after the divorce, which he attributed to their inability to maintain mortgage repayments. McCarthy \& Simpson (1991), who found the same gendered pattern, argued that also maintenance problems (costs and practicalities) led to divorced women moving out of owner-occupation in the somewhat longer run. In Wasoff and Dobash's (1990) study, only one in three custody parents with children (mostly women) were still living in the former matrimonial home three years after the divorce. A long-term risk of moving out of owner-occupation for women, compared to a temporary risk for men was also found for the Netherlands (Feijten, 2005).

\section{UK institutional and housing market context}

The UK housing market is dominated by owner-occupied housing. In 2007, $70 \%$ of the housing stock was owner-occupied, $18 \%$ was social rented and $12 \%$ was private rented (Department for Communities and Local Government, 2008). Owner-occupied housing used to be available for every budget, but as in most Western countries, house prices in the UK have increased significantly in the last decade (at least up to the end of 2007), making it increasingly difficult for new entrants into the housing market (including semi-new entrants such as divorcees) to buy a house. Access to the social rented sector is restricted and social housing is only available to those most in need, and there are long waiting list in most areas. Rents in the social rented sector are relatively low, and social tenants often qualify for housing benefit to pay the rent.

In the UK, divorce (the legal termination of a marriage) often involves a court decision on how the couple's assets are to be divided. If the couple owns a home, this is usually the couple's biggest asset and an important factor in settlement negotiations. After the introduction of the Matrimonial and Family Proceedings Act 1984, courts have often tried to establish a 'clean break': a financial settlement where the two parties have no ongoing commitments towards each other for the rest of their lives. A 'clean break' often took the form of the ex-wife getting the matrimonial home in return for giving up any claims to alimony payments by the ex-husband. This meant that after the divorce any outstanding mortgage payments, as well as child maintenance costs, were the sole responsibility of the ex-wife who was often forced to sell the matrimonial home as there was no sufficient income to cover the costs of living. Therefore this settlement of a clean break has become less common in the last decade (Mantle, 1996). Yet, mortgage payment arrears and forced exits from owneroccupation are still common among divorcees.

In $64 \%$ of the separating couples in rented accommodation, the ex-wife stays in the matrimonial home, while only $29 \%$ of the ex-husbands stayed (Holmans, 2000)). If a mother (plus her dependent children) is the leaving party, she may call upon the local council to find them a new place to live. As a result of the Housing (Homeless Persons) Act 1977, local authorities have the legal responsibility to accommodate families with minor aged children to protect them from homelessness (Mantle, 1996). In the past, local councils often allocated these families a council house, but as divorce rates went up, and the stock of social housing decreased, this has become increasingly difficult. As a result, local councils often offer accommodation in the private rented sector where the rent is paid, in full or in part, by Housing 
Benefit. Emergency accommodation offered immediately upon separation is often temporary, such as bed \& breakfasts, hostels and women's refuges.

When, in case of a separation, divorce or split up, ex-partners end up with a very low or no income at all, they can claim state benefits. For claiming means-tested benefits, it does not matter whether a couple was married or not. Anyone, regardless of marital status, who does not have the minimum income to maintain themselves and their dependents, can claim state benefit if they can prove they need it. In the case of cohabitors splitting up, no legal unbinding of the union is needed, and thus no court is involved in settling the division of a jointly owned dwelling. As cohabiting couples have lower owner-occupation rates than married couples (Holmans, 2000), break ups of cohabiting couples do not involve an owner-occupied home as often as divorces.

\section{Why splitting up and divorce affect the housing career and mobility}

There is a close relationship between household and housing careers in the life course. Live events such as getting married, and getting children often coincide (and are expected to coincide) with upward moves on the housing ladder (Rossi, 1955; Brown \& Moore, 1970; Michelson, 1977; Mulder \& Hooimeijer, 1999). Changes in household configurations lead to changing requirements with regard to the dwelling. The split up of unmarried cohabiting couples or the divorce of married couples inevitably results in major changes in the household configuration. For most people union dissolution involves the transition from living in a couple to living alone or with children, although some people immediately move on to forming a new partnership.

Not only the household configuration is changing, but also the roles people are expected to play and the associated set of norms. Simpson (1994) points out that union dissolution marks continuity and discontinuity in the life course at the same time: continuity in personal well-being and individual expression, and discontinuity in family life. Yet, although splitting up and divorce are widely accepted life choices, the roles people have to take on after union dissolution are much less clear compared to the well-defined role of being part of a family. The general lack of defined norms and role clarity may seep through into housing careers. Couples (are) often (expected to) aspire an upward housing career, which should ultimately lead to finding the ideal family home' (Perin, 1977; Duncan, 1982; Saunders, 1990). But when the marriage gets disrupted, so does the ideal. The norm of making upward steps on the housing ladder is absent after splitting up or divorce, and people might show a variety of housing behaviours resulting from individual choices about how to fulfil post-divorce roles.

Splitting up and divorce can be expected to have implications for the housing career because moves triggered by union dissolution are deviant compared to moves triggered by other life events since they are urgent and financially restricted (Feijten \& Van Ham, 2007). With 'urgent', we mean that once a decision to split up or to have a divorce is taken, partners usually want to effect that decision as soon as possible, implicating that at least one of them has to move out of the matrimonial home at short notice. Due to the urgency of the move, most people simply have to accept the first available option, often moving in with family or friends, into other shared housing, or into bed \& breakfast accommodation. Since many couples live in owner-occupied single family dwellings, this means a huge downswing in the housing situation for divorced movers. Feijten and Van Ham (2007) showed for the Netherlands that directly after a union dissolution people move more often than people in other living arrangements. Although their mobility rate decreased over time, it remained higher than the mobility rate of their married counterparts for several years after the event. 
This finding was interpreted as a series of moves needed to regain the quality of housing people prefer and were probably used to before the union dissolution.

Moves triggered by union dissolution are financially restricted because they often coincide with a steep decline in resources, especially when the personal income is lower than the prior household income. Financially, women often suffer more from union dissolution than men because they are more likely to have a low income or no income at all (Jarvis \& Jenkins, 1999; Aassve et al., 2006; Andress et al., 2006). A decline in recourses also occurs because of loss of economies of scale on the household level. Housing choices are obviously affected by a decline in resources as housing costs are likely to take up a larger share of the income after union dissolution. A particular problematic situation emerges when a couples lives in a heavily mortgaged house, and neither partner can afford to buy the other partner out. In this case both ex-partners have to move out, sell the matrimonial home and split the profit (or loss).

\section{Hypotheses}

The above lead us to formulate five hypotheses:

1. Divorced and split up people move more often than married and cohabiting people. The union dissolution itself leads to moving, and then a number of 'adjustment moves' may be needed to obtain suitable housing again.

2. Divorced and split up people move more often out of owner-occupation, and more often out of single family dwellings, than married and cohabiting people. The decrease in resources and loss of economies of scale jeopardise the affordability of an owner-occupied dwelling compared to a rented dwelling, and of a single family dwelling compared to an apartment. Also, rented accommodation offers more flexibility, which is often desirable in the post-divorce period when divorcees are unsure about how their future will develop.

3. The gap in housing 'quality' is bigger between divorced and married people than between split up and cohabiting people. On average, the married will have invested more in their housing situation than cohabiters, and therefore the fall back in housing quality can be expected to be larger after a divorce than after a split up.

4. Repartnered people move less often out of owner-occupation and more often into single-family dwellings than divorced and split up people. Starting a new relationship usually means an increase in household resources and economies of scale, which is likely to lead to upward moves on the housing ladder. Also, couples usually have different housing preferences than (divorced or split up) singles.

5. The negative effects of divorce and split up on the housing career are temporary. The break up may affect housing careers right upon the event, but after a while, once people are more settled in the new situation, and the novelty of the situation has worn off, most housing careers will be re-directed in an upward direction. Another way of expressing this is to say that the event of divorcing/splitting up causes increased mobility, and that the state of being divorced/split up does to a much lesser extent, but still more than the state of being married (because of the 'adjustment moves' needed to regain decent housing quality in the postdivorce/post-split-up period).

\section{DATA AND METHOD}




\section{Data}

This study used data from British Household Panel Survey (BHPS), which is a nationally representative stratified sample of 5,500 households (10,300 interviewed individuals) drawn in 1991 from 250 areas in Great Britain (Taylor et al., 2009). Additional booster samples for Scotland, Wales and Northern Ireland were added later, but for this study we only used the original 1991 sample. Since 1991, the same individuals have been re-interviewed each successive year on many topics. The latest year in our sample is 2004, which means that we had a panel of 14 successive years. For our analyses we only used respondents who were head of the household or the partner of the head of the household and who were in, or had ever been in, a relationship. We excluded person-years where the sample members were over 70 years old, and person-years when people were in full-time education. We also excluded person-years of widowhood because union dissolution as a result of widowhood is beyond the scope of this paper. Lastly, we excluded respondents with missing background information (such as income and tenure), and missing mover status. Because mover status is derived by comparing current and previous (one year ago) place of residence, mover status was unknown for everyone in the first year of the panel. As a result of this, all 1991-observations were discarded. The remaining sample contained 66,301 person-years representing 7,640 respondents. The number of years respondents were observed in our sample ranges from one year $(7.9 \%$ of respondents) to a complete series of 13 years (37.5\% of respondents).

In the first few waves of the BHPS, people were interviewed about their life histories, such as their fertility and relationship history. This allowed us to calculate the duration of the living arrangement they had in the first wave. Fertility histories meant that we could identify parents whose children do not live in their household (mostly non-custody fathers and a few non-custody mothers). A potential problem when studying mobility with panel data is that those who move are more likely to leave the panel compared to those who stay. Buck (2000) has shown that although this problem is present in the BHPS, its effect on the study of residential mobility and migration is limited because only a small percentage of movers disappear without leaving any information. However, there is a risk that those who disappear from the panel are disproportionately people who recently separated or divorced.

\section{Method and outcome variables}

We first analysed the occurrence of moving for all person-years in which respondents are married, cohabiting, divorced, split up, or in a new relationship. Next, for those who have moved we analysed the probability of moving out of single-family housing and home ownership. For each aspect of the housing career, we first analysed the association between the dependent variable and living arrangements in a base model, which does not control for other factors. We then added duration of living arrangement, and then controlled for the usual individual and household background variables. The risk of moving was analysed in a logistic panel model, because panel models are apt to capture the time dimension of being at risk of moving. Once we knew the risk structure of moving for people in different living arrangements, we subsequently analysed movers only. The risks of moving from owner-occupied housing into another tenure and of moving from a single-family dwelling into another type of dwelling were analysed using logistic regression models. Because sample members were at risk of multiple moves, the standard errors in our models were 
corrected for non-independent observations, using the Huber-White estimator (Huber, 1967).

\section{Variables}

The table in the Appendix give a selection of summary statistics for all the variables that we used in our models. A few of these variables need some additional explanation. The living arrangement variable was created by using marital status, which includes separate categories for 'living as a couple (unmarried)' and 'separated (still legally married but living apart)'. By comparing marital status in each wave with the relationship history, we were able to determine dissolutions of cohabiting unions and of married unions. This procedure also enabled us to determine when people entered a new relationship after a spell of being single after a split up or a divorce. Due to small numbers, we combined cohabitations and marriages and we labelled this category of second and higher order relationships as 'new relationship' in the tables. For those who were married, divorced or cohabiting at the time of the first wave, living arrangement duration was calculated using the reported start year of the living arrangement. A handful of people did not report the starting date of their current living arrangement and we solved this statistically by creating a dummy indicating a missing value on duration and substituting the missing duration by the mean duration of all other cases (see Cohen \& Cohen, 1975). The duration of 'split up' spells was calculated by simply counting panel years following the break up of a cohabitation spell ${ }^{1}$. If people changed living arrangement during the panel, the duration count started again at zero.

The variable indicating moving occurrence includes all moves. However, separating/divorce and splitting up induce moves almost by definition, because in most cases of union dissolution, of the partners leaves the joint home. Similarly, the start of a spell of cohabitation requires the move of at least one of the partners in order to become a cohabiting couple. This type of 'implied move' is absent for most married couples, because nowadays many transitions to marriage are made by couples who are already living together. By including these 'implied moves' in our move variable, the effect of separation, splitting up and cohabitation may be inflated compared to being married ${ }^{2}$.

\section{RESULTS}

\section{Moving occurrence}

We expected that divorced people would move more often than their married counterparts, and that people who split up move more often than their cohabiting counterparts (hypothesis 1). The results from Model 1 in Table 1 support the first part of the hypothesis, but not the second part. Those who have split up are as likely to move as those who cohabit. Once we control for duration of living arrangement and

\footnotetext{
${ }^{1}$ Some of the respondents were probably split up in the first year of the panel, but we don't know that because in the first wave there is no information on past cohabitations. We thus observe these respondents as never married singles, and left these person years out of the sample.

${ }^{2}$ We used a dependent variable which excluded moves in the year of the relationship event. This is a very crude way of excluding implied moves, but it was the best we could do with the data at hand. The effects of divorce, splitting up and cohabitation in these models were smaller (up to $80 \%$ smaller for divorce and split up in the occurrence models; and up to $40 \%$ smaller in the moving-out-of-owneroccupation and moving-out-of-single-family housing models). The effects remained largely significant (only sometimes not in the full models). The full results are available upon request from the authors.
} 
the interaction between living arrangement and duration in Model 2, the results fully support the hypothesis that divorced people move more often than their married counterparts, and that people who split up move more often than their cohabiting counterparts. The main effect of duration has a negative effect on the probability of moving for all living arrangements: the longer one is in a certain living arrangement, the lower is the likelihood of moving.

\section{--- TABLE 1 ---}

The interaction effect between living arrangement and duration in Model 2 allows us to check whether the effect of duration on the probability of moving works out differently for people in different living arrangements and whether the negative effects of divorce and split up on the housing career are temporary or not (hypothesis 5). The total of main effects and interaction effects of living arrangement and duration are plotted in Figure 2. It can be seen that the pace at which moving probability decreases with duration is very different for the five living arrangements. Those who recently experienced a split up or a divorced are more likely to move than their partnered counterparts, but the probability of moving decreases quickly with duration of living arrangement, especially for those who experienced a split up. The probability of moving for the divorced goes down much slower, and stays consistently higher than the probability of moving for the married. The findings lend support to our hypothesis that after a divorce, many people enter a period of frequent mobility. Even eight years after a divorce, the estimated moving probability for the divorced is still higher than for the married. Re-partnering after divorce lowers the moving probability, though not immediately: the probability of moving for those in a 'new relationship' is high at the start and only drops below that of divorcees halfway the third year, and reaches the same level as the married after five years. Hypothesis 5 stated the expectation that the effects of divorce and split up on housing careers are only temporary. The results in Figure 2 show that this is only true to a certain extent. There seems to be a long lasting effect on the occurrence of moving for all those involved in union dissolution.

Model 3 in Table 1 includes the same variables as Model 2, but also controls for a range of variables known to affect the probability of moving. All the effects of these control variables are as expected based on the relevant residential mobility literature (e.g. Rossi, 1955; Michelson 1977; Deurloo et al., 1987; Mulder, 1993). Including the control variables does not affect the general patterns discussed above.

\section{--- FIGURE 2 ---}

\section{Type of housing after split up and divorce}

Figure 3 shows the distribution of dwelling types that movers move into, by type of living arrangement (regardless of the dwelling type of origin). It can be seen that moving into single family dwellings is typically for couples, as it accounts for more than 80 per cent of destinations of moves by the married and those in a new relationship (hypothesis 4 ), and for almost $70 \%$ of moves by cohabiters. Moves into flats and apartments are most common among people without a relationship. Split up and divorced movers move about three times as often into flats as married movers. But note that this is also true for cohabiters. Moves back to the parental home are also much more common among movers who are divorced or split up. This is in line with the idea that such moves are urgent and financially restricted, because moving back in 
with parents is usually seen as a temporary solution. Finally, around $8 \%$ of moves by split up and divorced movers are into shared housing, against less than $5 \%$ for people in relationships. We also studied moves by size of dwelling (not shown; results can be requested from authors). The results clearly demonstrated that downsizing is more common among those who split up and divorce than among people in a relationship.

\section{--- FIGURE 3 ---}

Table 2 presents logistic regression models of the probability of moving out of a single-family dwelling. The parameters express the effect of the explanatory variables on the odds of moving out of single-family housing to moving within single-family housing. Model 1 shows that the odds of moving out are particularly high for the divorced and the split up, compared to the married. In Model 2, duration of the living arrangement is added, and interaction terms between living arrangement and duration. The main effect of duration is positive, but not significant. The interaction effects of living arrangements and duration are negative for all living arrangements. The combination of main effects and interaction effects indicate that all living arrangements are more likely to move out of single family dwellings than married people, but that this increased risk of moving out of single-family dwellings decreases (somewhat) with longer duration of the living arrangement. The interaction effect is only significant for people who cohabit and it takes them roughly 8 years to match the behaviour of the married. The results are contrary to what we expected in hypothesis 5: the negative effects of divorce and split up on the risk of moving out of a single family dwelling seem to be long lasting.

In Model 3, a range of control variables are added. These show that the odds of moving out of single-family housing decrease with age, income and birth cohort, and are lower for women and households with children. The main effects of living arrangement type remain strong and significant. The odd of moving out of singlefamily housing are still the highest for the split up and the divorced, which suggests a big immediate effect of the event of relationship breakdown on the risk of moving out of a single family dwelling. The main effect of duration is now negative and significant. Thus, the longer one spends in a certain living arrangement (including marriage), the lower the odds of moving out of single family housing. The interaction effect is still only significant for cohabitors, which means that only the behaviour of cohabitors becomes more similar to the behaviour of married people over time.

\section{--- TABLE 2 -.-}

\section{Tenure of housing after split up and divorce}

We hypothesised that those who split up or divorced are more likely to move out of owner-occupation than others, mainly because of financial reasons and partly because of the urgency of the move (hypothesis 2). We also hypothesised that people who repartner are less likely to move out of owner-occupation than those who split up or divorce (hypothesis 4). Figure 4 shows that indeed, the percentage of moves into owner-occupation is the highest for the married (73\%), followed by those in a new relationship (61\%). The percentages for the divorced and split up are considerably lower (39\% and 33\% respectively). Given that the owner-occupation rate among married people is high, a rate of only $39 \%$ moves into owner-occupation once the marriage breaks down is very low indeed. When we compare the percentage of moves into owner-occupation for the split up (33\%) with the percentage of moves into 
owner-occupation for the cohabiting (52\%), it can be seen that a split-up of unmarried cohabitation also leads to a considerable drop in moves into owneroccupied housing.

\section{--- FIGURE 4 ---}

Table 3 presents logistic regression model parameters of the odds of moving out of owner-occupation compared to moving within the owner-occupied sector. The models include homeowners only. The results show that splitting up and divorce lead to a strong increase in probability of moving out of owner-occupation. The odds ratio for divorcees is 5.5 times larger than for married couples (exp(1.71) from Model 1), and the odds ratio for those splitting up is almost three times larger than for cohabiters $(\exp (2.13) / \exp (1.11)$ from Model 1). Those in a new relationship are more likely to move out of owner-occupation than married couples, but much less likely than other categories.

When we include duration of living arrangement and the interaction effect between living arrangement and duration in the model, the main effects of living arrangement on the probability of moving out of owner-occupation change hardly compared to model 1 . The main effect of duration itself is small and insignificant, but the interaction effect between duration and living arrangement type is negative and significant for cohabiting and new relationship. For the people in these living arrangements, the risk of moving out of owner-occupation decreases when they are longer in their relationship. This implies that the risk does not go down for people who experienced a split-up or a divorce. For them, the risk of leaving an owneroccupied home remains high, even after some time.

In Model 3, we add a series of control variables, which does not alter the main effects of living arrangement type on the probability to leave home ownership very much. The effects of the interaction effects change slightly, but the general picture remains the same. The interaction effects show that of all living arrangement types, being divorced or split up leads to the slowest decrease in the probability of moving out of owner-occupation. This indicates that the risk of moving out of owneroccupation remains relatively high for several years after union dissolution for these two groups. The total of the main effects and interaction effects of living arrangement type and duration indicates that it will take all living arrangement types a considerable number of years before they would equal the low probability of moving out of owneroccupation of the married (the base category). Five years after the divorce, divorcees are still almost five times as likely to move out of owner-occupation than people who have been married for five years. Apparently, divorcees who managed to stay in the matrimonial home upon separation (which is $70 \%$ of divorcees in our data) face increasing difficulties to meet maintenance costs, practicalities, and mortgage repayments over time (see also Feijten, 2005). Separate analysis for men and women showed no significant gender differences. The results show only limited support for hypothesis 5 that the negative effects of splitting up and divorce on housing careers are only temporary.

\section{--- TABLE 3 ---}

In a new relationship after divorce or splitting up

All our results show that housing careers of those who experienced a union dissolution are likely to recover when people start a new relationship after a split up 
or a divorce. The probabilities of moving out of owner-occupation and out of singlefamily housing were higher for people in a new relationship than in an unbroken marriage (the base category), but much lower than for those who were split up or divorced. This confirms hypothesis 4 . Duration of the new relationship had no effect on the risk of moving our of single-family housing, but it did have a negative effect on the risk of moving out of owner-occupation. This may well be a financial effect where pooling resources with the new partner makes it easier to keep up mortgage payments, but also the practical responsibilities of home ownership are easier to bear with a partner.

\section{CONCLUSION AND DISCUSSION}

The main contribution of this paper to the existing literature on the effect of union dissolution on housing careers was that we included those who split-up and those who divorced as separate living arrangement categories and that we also included those who formed new relationships in the analyses. We studied the effect of living arrangements and the effect of the duration of living arrangements on housing careers to investigate whether there are any long term effects of union dissolution on housing careers.

Our results are broadly in line with the literature on the effects of divorce on housing careers from the 1980s and 1990s: union dissolutions have severe implications for housing careers and generally lead to downward moves on the housing ladder. Both those who split-up and those who separate/divorce are more likely to move out of single-family dwellings and are more likely to leave owneroccupation. Those who split up are more frequent movers than those who are cohabiting and those who are divorced are more frequent movers than those who are married. All those involved in union dissolution are relatively frequent movers. It is important to note that our data most likely underestimates the occurrence of moves for those involved in union dissolution as panel studies are likely to loose mobile respondents. In addition, the BHPS only allowed us to identify one move per year while those who are involved in union dissolution are likely to make more than one move per year, especially in the initial phase of union dissolution. The move out of the formally joint dwelling is the first but often not the last move. After union dissolution, people's first move is often into temporary accommodation, which means that one or more follow-up moves have to be made before finding suitable, more permanent housing. A (sharp) decrease in resources, a change in housing preferences, and the disappearance of economies of scale all contribute to the need for making adjustment moves before a new satisfactory housing situation is obtained. On the national level, this leads to increased mobility in the population which experienced a union dissolution compared to those who are in a union.

The results clearly show that the differences in housing behaviour between the divorced and the married are larger than the differences between those who cohabit and those who split up. This implies that the gap in housing 'quality' is bigger between divorced and married people than between split up and cohabiting people. On average, the married will have invested more in their housing situation than cohabiters, and therefore there is more to loose for them. For a large proportion of cohabiters, the period of cohabitation is still a potentially dynamic phase in life as $30 \%$ of cohabitations ends in splitting up (Ermisch \& Francesconi, 2000). Because the commitment made to a cohabiting partner is on average weaker than commitments 
made to a married partner, the consequences of breaking up are less severe for cohabiters than for the married. It is worth noting that cohabiters usually live in more modest housing than married people do, and that this is likely to be related to their age and their life course phase, and possibly to life style. So while the figures for cohabiters who split up are less dramatic than for the married, this is most likely due to the more modest housing situation they were in to start with. A couple with faith in their future together are more likely to get married, but are also more likely to buy a single family dwelling (we have labelled this 'long-stay housing' in a previous paper: Feijten et al., 2002). Thus, those with long-term plans select themselves into marriage and as a result, the category of cohabiters consists largely of relatively uncommitted people who are still at the bottom of the housing ladder. Married couples are often further in their housing career than unmarried cohabiters, so for the married there is a lot to lose in the case of a divorce. On the other hand, divorcees may be better able to maintain a decent housing standard after divorce than cohabiters are after a break-up, because on average they have a better and more stable labour market position and more financial assets.

Starting a new relationship after divorce or splitting up was found to improve housing conditions compared to those who remained single after union dissolution. In our analyses the effects for those in a new relationship were much more similar to the category 'married' than to the categories 'divorced' or 'split up'. This also confirms findings from earlier literature (Murphy, 1990; Holmans, 2000).

Contrary to what we expected, we found that the effects of splitting up and divorce on housing career was more long lasting than temporary. Over time, those who experienced a union dissolution show a drop in the occurrence of moves. This drop is most pronounced for those who experienced a split-up. However, there is hardly any decrease with duration in the risk of moving out of single-family dwellings and the risk to move out of owner-occupation. This implies that the effects of union dissolution (from both cohabitation and marriage) on housing careers are long lasting. The final conclusion of this paper is that including cohabiters and those who experienced a split-up have enriched our understanding of the effects of union dissolution on housing careers. The results imply that those who cohabit are generally less committed than those who are married, but that also for cohabitors a union dissolution can have severe and long lasting effects on the housing career.

Disclaimer: The data used in this paper were made available through the ESRCData Archive. The data were originally collected by the ESRC Research Centre on Microsocial Change at the University of Essex (now incorporated within the Institute for Social and Economic Research). Neither the original collectors of the data nor the Archive bear any responsibility for the analyses or interpretations presented here.

\section{References}

Aassve, A., Betti, G., Mazzuco, S. \& Mencarini, L. (2006) Marital disruption and economic well-being: a comparative analysis. ISER Working paper 2006-07.

Amato, P. R. (2000) The consequences of divorce for adults and children, Journal of Marriage and the Family, 62, pp. 1269-1287.

Andress, H. J., Borgloh, B., Bro“ckel, M., Giesselmann, M. \& Hummelsheim, D. (2006) The economic consequences of partnership dissolution: a comparative 
analysis of panel studies from Belgium, Germany, Great Britain, Italy, and Sweden, European Sociological Review, 22(5), pp. 533-560.

BHPS British Household Panel Survey [computer file] (2007) principal investigator, ESRC Research Centre on Micro-social Change (Colchester: The Data Archive) [distributor].

Boheim, R. \& Taylor, M. P. (2000) My home was my castle: evictions and repossessions in Britain, Journal of Housing Economics, 9, pp. 287-319.

Brown, L. A. \&Moore, E. G. (1970) The intra-urban migration process: a perspective, Geografiska Annaler B, 52, pp. 1-13.

Buck, N. (2000) Using panel surveys to study migration and residential mobility: researching social and economic change, in: D. Rose (Ed.) The Uses of Household Panel Studies (London: Routledge).

Clapham, D., Kemp, P. \& Smith, S. (1990) Housing and Social Policy (London: Palgrave Macmillan).

Cohen, J. \& Cohen, P. (1975) Applied Multiple Regression/Correlation Analysis for the Behavioral Sciences (Hillsdale, NJ: Erlbaum).

Department for Communities and Local Government (2008) Housing in England 2006/07: A report based on the 2006/07 Survey of English Housing, carried out by the National Centre for Social Research (London: Department for Communities and Local Government).

Deurloo, R. C., Dieleman, F. M. \& Clark, W. A. V. (1987) Tenure choice in the Dutch housing market, Environment and Planning A, 19, pp. 763-781.

Duncan, N. G. (1982) Home ownership and social identity, in: J. S. Duncan (Ed.) Housing and Identity (New York: Holmes \& Meier).

Ermisch, J. F. \& Francesconi, M. (2000) Cohabitation in Great Britain: not for long, but here to stay, Journal of the Royal Statistical Society: Series A (Statistics in Society), 163(2), pp. 153-171.

Feijten, P. (2005) Union dissolution, unemployment and moving out of homeownership, European Sociological Review, 21, pp. 59-71.

Feijten, P. \& Mulder, C. H. (2002) The timing of household events and housing events in The Netherlands: a longitudinal perspective, Housing Studies, 17, pp. 773-792.

Feijten, P. \& van Ham, M. (2007) Residential mobility and migration of the separated, Demographic Research, 17(21), pp. 623-654.

Feijten, P., Mulder, C. H. \& Baizan, P. (2003) Age differentiation in the effect of household situation on first-time homeownership, Journal of Housing and the Built Environment, 18, pp. 233-255.

Flowerdew, R. \& Al-Hamad, A. (2004) The relationship between marriage, divorce and migration in a British dataset, Journal of Ethnic and Migration Studies, 30, pp. 339-351.

Holmans, A. E. (2000) Divorce, Remarriage and Housing: The Effects of Divorce, Remarriage, Separation and the Formation of New Couple Households on the Number of Separate Households and Housing Demand and Conditions (London: Department of the Environment, Transport and Regions).

Huber, P. J. (1967) The behavior of maximum likelihood estimates under nonstandard conditions, in: Proceedings of the Fifth Berkeley Symposium on Mathematical Statistics and Probability 1 (Berkeley, CA: University of California Press).

Jackson, A. A. (1990) Relationship breakdown: the individual and local authority response, in: P. Symon (Ed.) Housing and Divorce (Glasgow: Centre for Housing Research). 
Jarvis, S. \& Jenkins, S. P. (1999) Marital splits and income changes: evidence from the British Household Panel Survey, Population Studies, 53, pp. 237-254.

Kiernan, K. E. \& Estaugh, V. (1993) Cohabitation: Extra-Marital Childbearing and Social Policy (London: Family Policy Studies Centre).

Mantle, W. (1996) The Handbook of Separation and Divorce (London: Routledge).

McCarthy, P. \& Simpson, B. (1991) Issues in Post-Divorce Housing: Family Policy or Housing Policy? (Aldershot: Avebury).

Michelson, W. (1977) Environmental Choice, Human Behavior, and Residential Satisfaction (New York: Oxford University Press).

Mulder, C. H. (1993) Migration Dynamics: A Life Course Approach (Amsterdam: Thesis Publishers).

Mulder, C. H. \& Hooimeijer, P. (1999) Residential relocations in the life course, in: L. J. G. van Wissen \& P. A. Dykstra (Eds) Population Issues: An Interdisciplinary Focus (The Hague: NIDI).

Murphy, M. J. (1990) Housing consequences of marital breakdown and remarriage, in: P. Symon (Ed.) Housing and Divorce (Glasgow: Centre for Housing Research).

ONS (2007a) Divorces: 1957-2003, Couples, and children of divorced couples. Taken from Table 5.4. Published in Marriage and Divorce Statistics (Historical series FM2 No. 16), Table 4.4 in FM2 Volume No. 18 and Table 4.10 in FM2 Volume No. 27 to 31 (London: Office for National Statistics).

ONS (2007b) Marriages, type of ceremony and denomination. Taken from Table 3.8a. Published in Marriage and Divorce Statistics (Historical series FM2 Vol. No. 16), Table 3.10 in FM2 Vol. No. 20, and Tables 3.29 in FM2 Vol. Nos. 26 to 31 (London: Office for National Statistics).

ONS (2007c) Age and previous marital status, 1961-2003: a. males. Taken from Table 3.2 published in Marriage and Divorce Statistics (Historical series FM2 Vol. No 16), Table 3.6 in FM2 Vol. Nos. 11 to 23, and Table 3.18 in FM2 Vol. Nos. 24 to 31 (London: Office for National Statistics).

ONS (2007d) Live births: 1961-2004, within/outside marriage and sex, a. all live births. Taken from: Table 3.1 published in Birth Statistics 1837-1983 (Historical series FM1 No 13), and Table 3.2 in FM1 Vol. Nos. 11 to 33 (London: Office for National Statistics).

Perin, C. (1977) Everything in Its Place: Social Order and Land Use in America (Princeton, NJ: Princeton University Press).

Poortman, A. R. \& Fokkema, T. (2001) Economische gevolgen van echtscheiding voor mannen en vrouwen in Nederland, 1949-1998 [Economic consequences of divorce for men and women in the Netherlands, 1949-1998], Sociale Wetenschappen, 44, pp. 69-92.

Rindfuss, R. R. \& Vandenheuvel, A. (1990) Cohabitation: a precursor to marriage or an alternative to being single, Population and Development Review, 16, pp. 703-726.

Rossi, P. H. (1955) Why Families Move: A Study in the Social Psychology of Urban Residential Mobility (Glencoe, IL: Free Press).

Saunders, P. (1984) Beyond housing classes: the sociological significance of private property rights in means of consumption, International Journal of Urban and Regional Research, 8, pp. 202-227.

Schouw, R. J. \& Dieleman, F. M. (1987) Echtscheiding en woningmarkt: een voorstudie naar de complexe relatie tussen echtscheiding en de woningmarkt 
[Divorce and housing market: A pre-study into the complex relationship between divorce and the housing market] (Utrecht: KNAG).

Simpson, B. (1994) Bringing the 'unclear' family into focus: divorce and re-marriage in contemporary Britain, Man, New Series, 29, pp. 831-851.

South, S. J. \& Crowder, K. D. (1998) Avenues and barriers to residential mobility among single mothers, Journal of Marriage and the Family, 60, pp. 866-877.

Sullivan, O. (1986) Housing movements of the divorced and separated, Housing Studies, 1, pp. 35-48.

Symon, P. (1990) Marital breakdown, gender and home ownership: the owneroccupied home in separation and divorce, in: P. Symon (Ed.) Housing and Divorce (Glasgow: Centre for Housing Research).

Taylor, M. F. (Ed.) with Brice, J., Buck, N. \& Prentice-Lane, E. (2009) British Household Panel Survey User Manual Volume A: Introduction, Technical Report and Appendices (Colchester: University of Essex).

Van Noortwijk, L., Hooimeijer, P. \& Dieleman, F.M. (1992) Divorce and the disruption of the housing career, in: P. Korcelli \& J. Van Weesep (Eds) Housing and Urban Policy in Transition (Warsaw: PAN IGiPZ).

Wasoff, F. \& Dobash, R. (1990) Moving the family: changing housing circumstances after divorce, in: P. Symon (Ed.) Housing and Divorce (Glasgow: Centre for Housing Research).

Watchman, P. Q. (1990) Relationship breakdown, homelessness and the law, in: P. Symon (Ed.) Housing and Divorce (Glasgow: Centre for Housing Research).

Wilcox, S. (2003) UK Housing Review 2003/2004 (Coventry: Chartered Institute for Housing). 
FIGURE 1. Marriage, remarriage, cohabitation and divorce time series, UK, 1960-2005. Source: ONS (2007a, 2007b, 2007c, 2007d) (own calculations). Crown copyright material is reproduced with the permission of the Controller Office of Public Sector Information (OPSI).

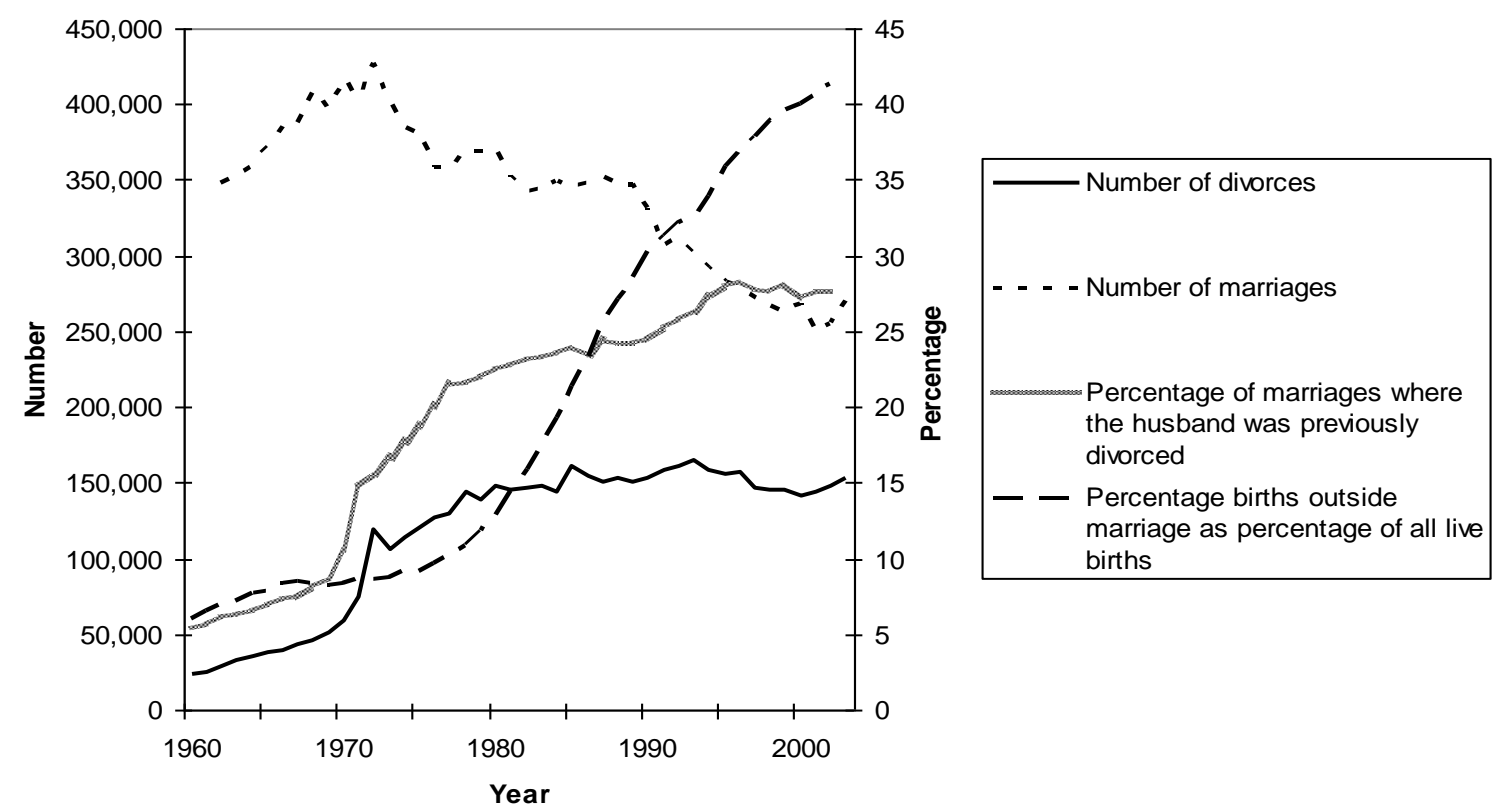


TABLE 1. Logistic regression of the annual probability of moving ( $\mathrm{ref}=$ not moving)

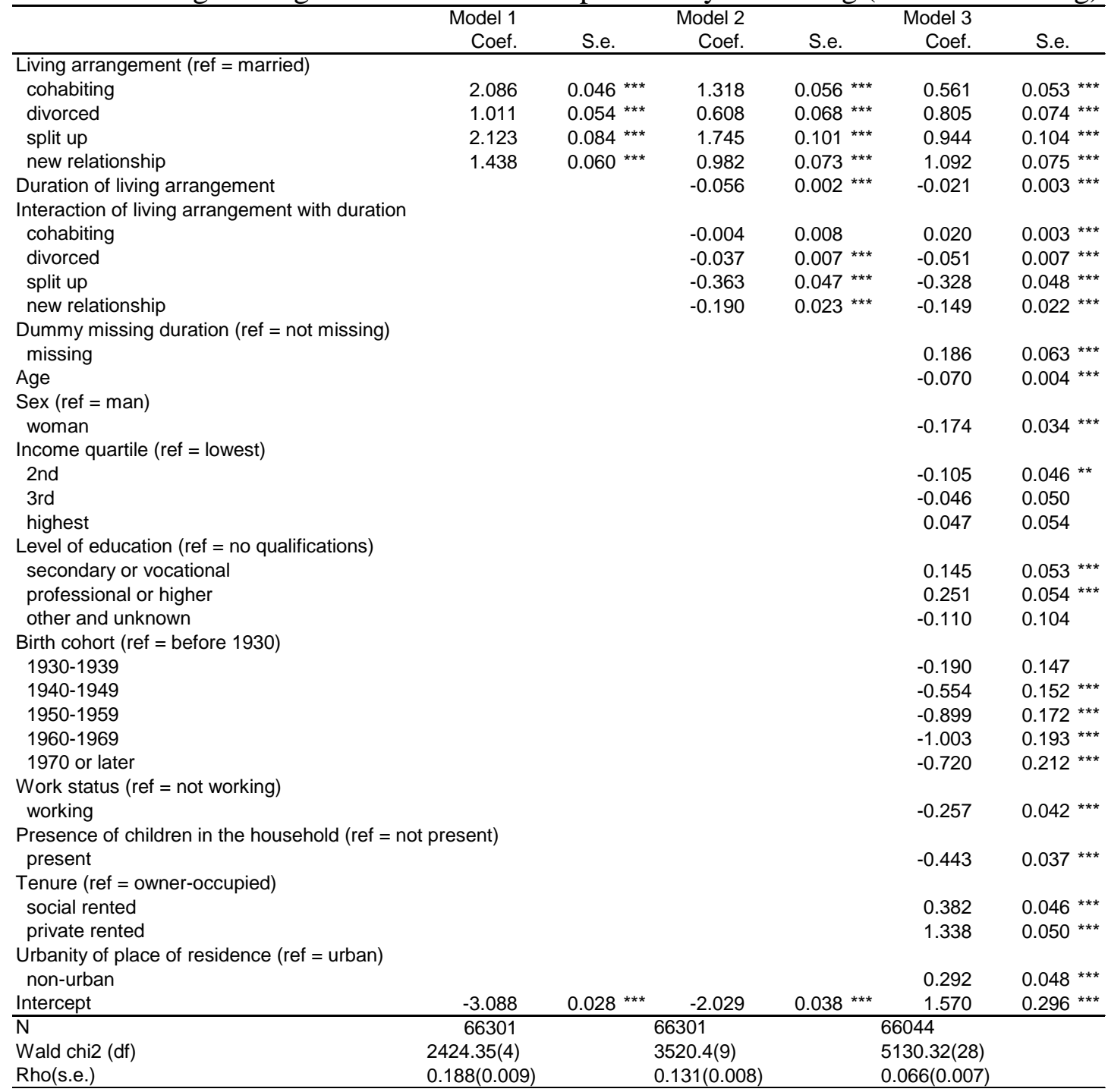

Source: British Household Panel Survey (own calculations) 
FIGURE 2. Estimated annual risk of moving, by living arrangement and duration (based on Model 2 of Table 1)

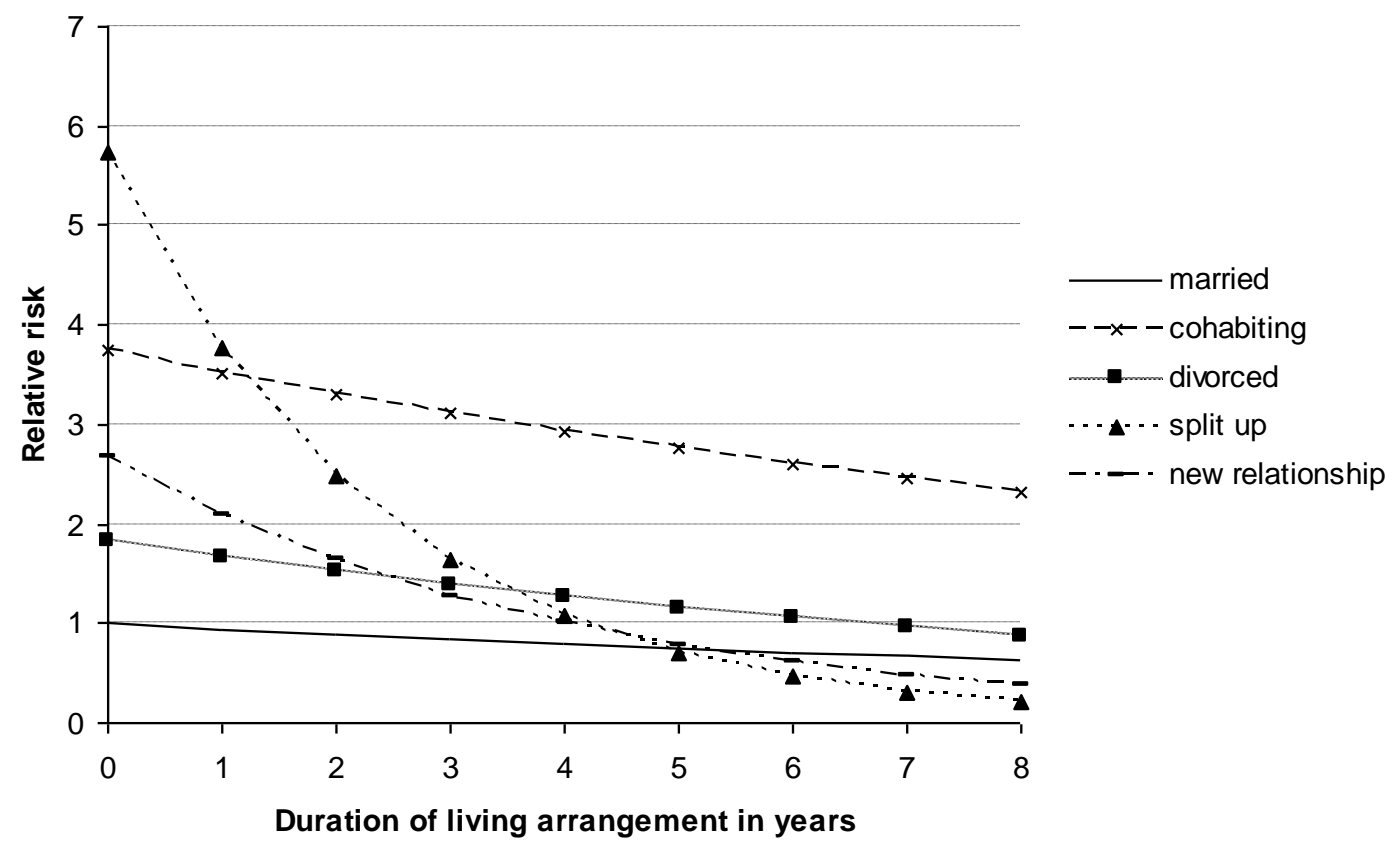

Source: British Household Panel Survey (own calculations)

FIGURE 3. Destination of moves in terms of dwelling type, by living arrangement $(\mathrm{N}=6,311)$

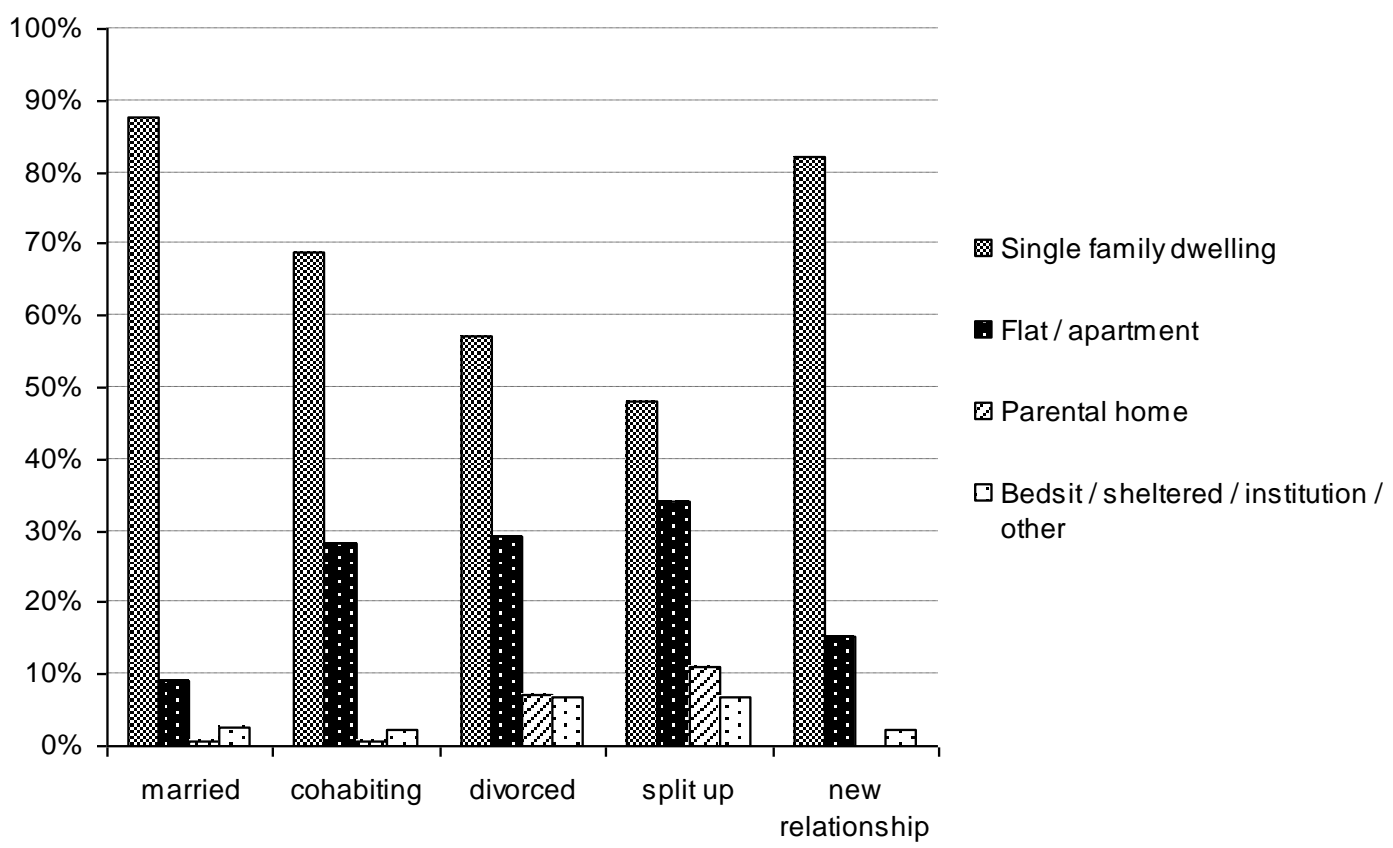

Source: British Household Panel Survey (own calculations) 
TABLE 2. Logistic regression of the annual probability of moving out of singlefamily housing ( $\mathrm{ref}=$ moving within single-family sector); movers from single-family dwellings only

\begin{tabular}{|c|c|c|c|c|c|c|}
\hline & \multicolumn{2}{|l|}{ Model 1} & \multirow{2}{*}{$\begin{array}{r}\text { Model } 2 \\
\text { Coef. }\end{array}$} & \multicolumn{3}{|c|}{ Model 3} \\
\hline & Coef. & S.e. & & S.e. & Coef. & S.e. \\
\hline \multicolumn{7}{|c|}{ Living arrangement (ref $=$ married) } \\
\hline cohabiting & 1.115 & $0.140^{* * *}$ & 1.669 & $0.193 * * *$ & 0.962 & $0.200^{* * *}$ \\
\hline divorced & 1.814 & $0.132 * * *$ & 2.062 & $0.182 * * *$ & 1.537 & $0.207^{\star * *}$ \\
\hline split up & 2.203 & $0.177^{\star \star *}$ & 2.439 & $0.227^{\star * \star}$ & 1.409 & $0.242^{* * *}$ \\
\hline new relationship & 0.499 & $0.169^{* * *}$ & 0.756 & $0.227^{* * *}$ & 0.527 & $0.231^{\star *}$ \\
\hline Duration of living arrangement & & & 0.010 & 0.007 & -0.020 & $0.008^{* * *}$ \\
\hline \multicolumn{7}{|c|}{ Interaction of living arrangement with duration } \\
\hline cohabiting & & & -0.222 & $0.052 * * *$ & -0.148 & $0.039 * * *$ \\
\hline divorced & & & -0.031 & $0.017 *$ & -0.030 & 0.020 \\
\hline split up & & & -0.097 & 0.100 & -0.066 & 0.099 \\
\hline new relationship & & & -0.071 & 0.071 & -0.053 & 0.077 \\
\hline \multicolumn{7}{|c|}{ Dummy missing duration (ref $=$ not missing) } \\
\hline missing & & & & & 0.818 & $0.241^{\star * *}$ \\
\hline Age & & & & & -0.040 & $0.014^{* * *}$ \\
\hline \multicolumn{7}{|l|}{ Sex $($ ref $=$ man $)$} \\
\hline woman & & & & & -0.277 & $0.111^{\star * *}$ \\
\hline \multicolumn{7}{|l|}{ Income quartile (ref = lowest) } \\
\hline 2nd & & & & & -0.644 & 0.142 *** \\
\hline 3rd & & & & & -0.722 & 0.162 *** \\
\hline highest & & & & & -0.924 & $0.173^{* \star *}$ \\
\hline \multicolumn{7}{|c|}{ Level of education (ref $=$ no qualifications) } \\
\hline secondary or vocational & & & & & -0.324 & $0.169 *$ \\
\hline professional or higher & & & & & -0.300 & $0.175^{*}$ \\
\hline other and unknown & & & & & -0.398 & 0.357 \\
\hline \multicolumn{7}{|l|}{ Birth cohort (ref $=$ before 1930 ) } \\
\hline $1930-1939$ & & & & & -1.099 & $0.437^{* * *}$ \\
\hline $1940-1949$ & & & & & -1.784 & $0.457^{\star * *}$ \\
\hline $1950-1959$ & & & & & -2.374 & $0.559 * * *$ \\
\hline $1960-1969$ & & & & & -2.232 & $0.646^{* * *}$ \\
\hline 1970 or later & & & & & -2.383 & 0.720 *** \\
\hline \multicolumn{7}{|l|}{ Work status (ref $=$ not working) } \\
\hline working & & & & & -0.242 & 0.142 * \\
\hline \multicolumn{7}{|c|}{ Presence of children in the household (ref $=$ not present) } \\
\hline present & & & & & -1.259 & 0.132 *** \\
\hline \multicolumn{7}{|c|}{ Urbanity of place of residence (ref = urban) } \\
\hline non-urban & & & & & -0.099 & 0.164 \\
\hline Intercept & -2.450 & 0.089 & -2.618 & 0.145 & 3.377 & $1.055^{\text {*** }}$ \\
\hline $\mathrm{N}$ & 3577 & & 3577 & & 3477 & \\
\hline Wald chi2(df) & $273.06(4)$ & & $302.81(9)$ & & $2.58(26)$ & \\
\hline
\end{tabular}

Source: British Household Panel Survey (own calculations) 
FIGURE 4. Destination of moves in terms of dwelling tenure, by living arrangement $(\mathrm{N}=6,311)$

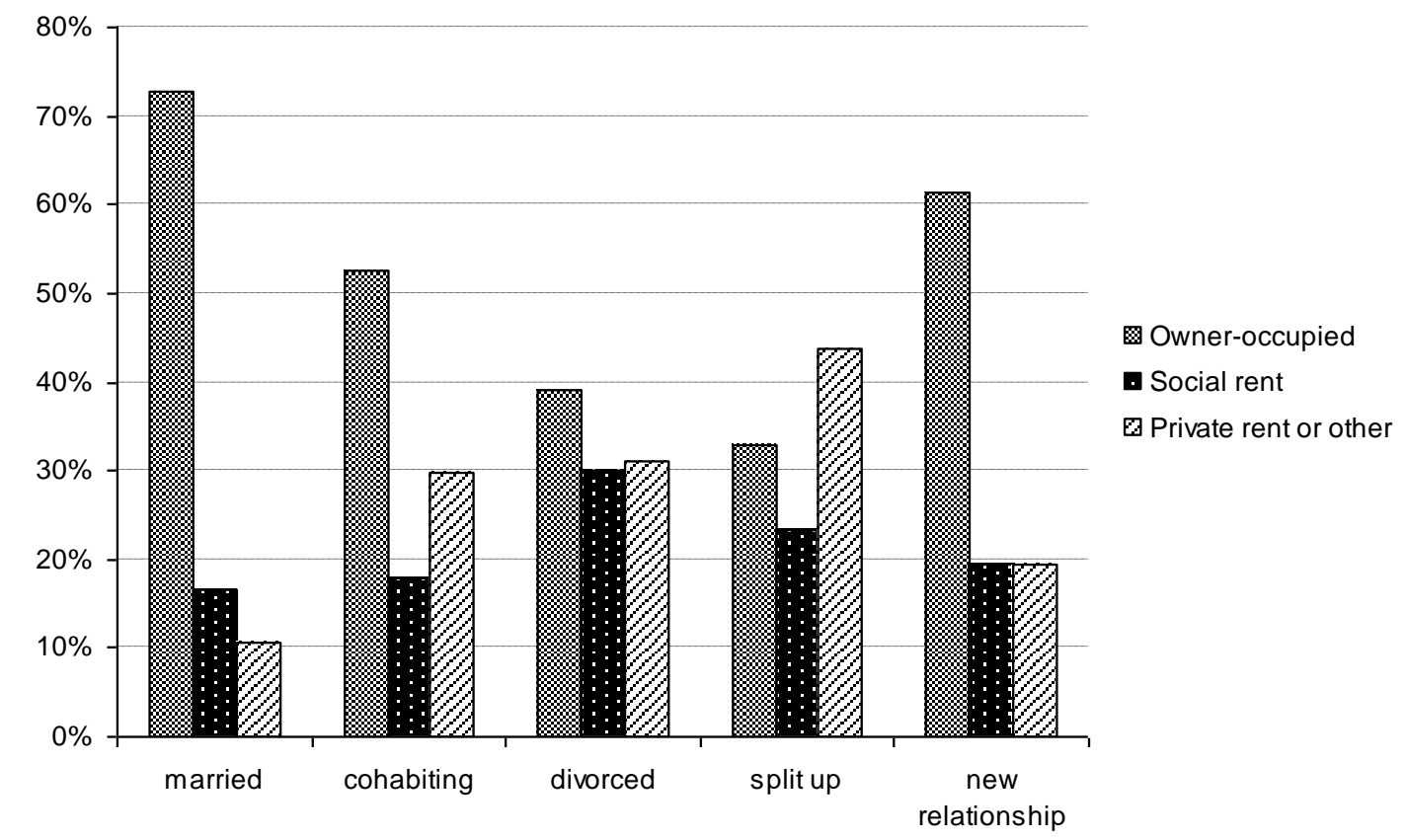

FIGURE 4. Destination of moves in terms of dwelling tenure, by living arrangement $(\mathrm{N}=6,311)$ 
TABLE 3. Logistic regression of the annual probability of moving out of owneroccupation ( $\mathrm{ref}=$ moving within owner-occupation); moving homeowners only

\begin{tabular}{|c|c|c|c|c|c|c|}
\hline & \multicolumn{2}{|l|}{ Model 1} & \multirow{2}{*}{$\begin{array}{r}\text { Model } 2 \\
\text { Coef. }\end{array}$} & \multicolumn{3}{|c|}{ Model 3} \\
\hline & Coef. & S.e. & & S.e. & Coef. & S.e. \\
\hline \multicolumn{7}{|l|}{ Living arrangement (ref = married) } \\
\hline cohabiting & 1.113 & $0.132 * * *$ & 1.299 & $0.188^{* * *}$ & 1.058 & $0.194 * * *$ \\
\hline divorced & 1.715 & $0.132 * \star *$ & 1.737 & $0.175^{* * *}$ & 1.718 & $0.217^{* * *}$ \\
\hline split up & 2.128 & $0.191^{* * *}$ & 2.042 & $0.234^{* * *}$ & 1.516 & $0.260^{* * *}$ \\
\hline new relationship & 0.576 & $0.160^{* * *}$ & 0.703 & $0.203^{* * *}$ & 0.878 & $0.219 * * *$ \\
\hline Duration of living arrangement & & & -0.006 & 0.007 & 0.003 & 0.009 \\
\hline \multicolumn{7}{|c|}{ Interaction of living arrangement with duration } \\
\hline cohabiting & & & -0.155 & $0.071^{* *}$ & -0.109 & 0.053 \\
\hline divorced & & & -0.029 & 0.021 & -0.040 & 0.024 * \\
\hline split up & & & -0.004 & 0.131 & 0.027 & 0.143 \\
\hline new relationship & & & -0.170 & $0.078^{* *}$ & -0.146 & 0.078 * \\
\hline \multicolumn{7}{|c|}{ Dummy missing duration ( $r e f=$ not missing) } \\
\hline missing & & & & & 0.552 & 0.233 \\
\hline Age & & & & & -0.055 & $0.014^{* * *}$ \\
\hline \multicolumn{7}{|l|}{ Sex $(r e f=\operatorname{man})$} \\
\hline woman & & & & & -0.343 & $0.109 * * *$ \\
\hline \multicolumn{7}{|l|}{ Income quartile (ref = lowest) } \\
\hline 2nd & & & & & -0.813 & 0.149 \\
\hline $3 r d$ & & & & & -0.942 & $0.155^{* * *}$ \\
\hline highest & & & & & -1.064 & $0.161^{* * *}$ \\
\hline \multicolumn{7}{|c|}{ Level of education (ref $=$ no qualifications) } \\
\hline secondary or vocational & & & & & -0.273 & 0.199 \\
\hline professional or higher & & & & & -0.143 & 0.195 \\
\hline other and unknown & & & & & -0.301 & 0.414 \\
\hline \multicolumn{7}{|l|}{ Birth cohort (ref = before 1930) } \\
\hline $1930-1939$ & & & & & 0.535 & 0.616 \\
\hline $1940-1949$ & & & & & -0.060 & 0.630 \\
\hline $1950-1959$ & & & & & 0.063 & 0.688 \\
\hline $1960-1969$ & & & & & -0.281 & 0.747 \\
\hline 1970 or later & & & & & -0.272 & 0.807 \\
\hline \multicolumn{7}{|l|}{ Work status (ref $=$ not working) } \\
\hline working & & & & & -0.720 & $0.143 * * *$ \\
\hline \multicolumn{7}{|c|}{ Presence of children in the household (ref $=$ not present) } \\
\hline present & & & & & -0.149 & 0.119 \\
\hline \multicolumn{7}{|c|}{ Urbanity of place of residence (ref $=$ urban) } \\
\hline non-urban & & & & & 0.210 & 0.146 \\
\hline Intercept & -2.039 & $0.077^{\star * *}$ & -1.946 & $0.125^{* * *}$ & 2.250 & 1.079 ** \\
\hline $\bar{N}$ & 3008 & & 3008 & & 2922 & \\
\hline Wald chi2(df) & $249.27(4)$ & & $267.32(9)$ & & $5.35(26)$ & \\
\hline
\end{tabular}

Source: British Household Panel Survey (own calculations) 
APPENDIX Summary variable descriptives and statistics (Total $\mathrm{N}=66,301$ )

\begin{tabular}{|c|c|c|}
\hline & $\mathbf{N}$ & $\%$ \\
\hline \multicolumn{3}{|l|}{ Move status } \\
\hline no move & 59,990 & $90.5 \%$ \\
\hline move & 6,311 & $9.5 \%$ \\
\hline \multicolumn{3}{|l|}{ Move out of owner-occupation } \\
\hline not at risk & 14,408 & $21.7 \%$ \\
\hline at risk & 48,885 & $73.7 \%$ \\
\hline move to other owner-occupied dwelling & 2,396 & $3.6 \%$ \\
\hline move out of owner-occupation & 612 & $0.9 \%$ \\
\hline \multicolumn{3}{|l|}{ Move out of single-family dwelling } \\
\hline not at risk & 9,291 & $14.0 \%$ \\
\hline at risk & 53,433 & $80.6 \%$ \\
\hline move to other single-family dwelling & 3,006 & $4.5 \%$ \\
\hline move out of single-family dwelling & 571 & $0.9 \%$ \\
\hline \multicolumn{3}{|l|}{ Living arrangement } \\
\hline married & 49,479 & $74.6 \%$ \\
\hline cohabiting & 5,716 & $8.6 \%$ \\
\hline divorce/separation from marital partner & 6,237 & $9.4 \%$ \\
\hline split-up from cohabitation partner & 1,213 & $1.8 \%$ \\
\hline new relationship & 3,656 & $5.5 \%$ \\
\hline \multicolumn{3}{|l|}{ Missing duration dummy } \\
\hline not missing & 59,943 & $90.4 \%$ \\
\hline missing & 6,358 & $9.6 \%$ \\
\hline \multicolumn{3}{|l|}{ Sex } \\
\hline male & 30,495 & $46.0 \%$ \\
\hline female & 35,806 & $54.0 \%$ \\
\hline \multicolumn{3}{|c|}{ Income quartile (disposable annual household income) } \\
\hline lowest $(<£ 14,000)$ & 14,882 & $22.4 \%$ \\
\hline 2nd $(£ 14,000-£ 23,000)$ & 16,494 & $24.9 \%$ \\
\hline $3 r d(£ 23,000-£ 34,000)$ & 16,807 & $25.3 \%$ \\
\hline highest $(>£ 34,000)$ & 18,118 & $27.3 \%$ \\
\hline \multicolumn{3}{|l|}{ Highest completed level of education } \\
\hline below secondary / no education & 14,212 & $21.4 \%$ \\
\hline secondary or vocational & 24,494 & $36.9 \%$ \\
\hline professional or higher & 25,249 & $38.1 \%$ \\
\hline other or unknown & 2,346 & $3.5 \%$ \\
\hline \multicolumn{3}{|l|}{ Birth cohort } \\
\hline before 1930 & 2,595 & $3.9 \%$ \\
\hline 1930-1939 & 9,234 & $13.9 \%$ \\
\hline 1940-1949 & 16,072 & $24.2 \%$ \\
\hline 1950-1959 & 16,546 & $25.0 \%$ \\
\hline $1960-1969$ & 16,117 & $24.3 \%$ \\
\hline 1970 or later & 5,737 & $8.7 \%$ \\
\hline \multicolumn{3}{|l|}{ Labour market status } \\
\hline not working & 19,184 & $28.9 \%$ \\
\hline working & 47,117 & $71.1 \%$ \\
\hline \multicolumn{3}{|l|}{ Tenure } \\
\hline owner-occupied & 52,654 & $79.4 \%$ \\
\hline social rented & 10,082 & $15.2 \%$ \\
\hline private rented or other & 3,565 & $5.4 \%$ \\
\hline \multicolumn{3}{|l|}{ Presence of children in the household } \\
\hline not present & 39,005 & $58.8 \%$ \\
\hline present & 27,296 & $41.2 \%$ \\
\hline \multicolumn{3}{|l|}{ Urban indicator } \\
\hline urban & 58,237 & $87.8 \%$ \\
\hline non-urban & 7,807 & $11.8 \%$ \\
\hline \multirow{2}{*}{ unknown } & 257 & $0.4 \%$ \\
\hline & Mean & s.d. \\
\hline Living arrangement duration & 16.9 & 15.4 \\
\hline Age & 45 & 12.6 \\
\hline
\end{tabular}

Source: British Household Panel Survey (own calculations) 